\title{
Analisis kebutuhan dan perilaku ABK tuna rungu dan wicara dalam pembelajaran matematika dasar di SKh Kabupaten Pandeglang
}

\author{
Linda, Ajeng Muliasari \\ STKIP Syekh Manshur. Pandeglang, Indonesia. \\ E-mail: linda90linda@gmail.com, ajengmulia7@gmail.com
}

\begin{abstract}
ABSTRAK
Penelitian ini bertujuan untuk mengetahui kebutuhan dan perilaku Anak Tuna rungu dan Wicara dalam pembelajaran matematika dasar di Sekolah Khusus Kabupaten Pandeglang. Penelitian ini penting dilakukan untuk mengetahui bagaimana perilaku dan kebutuhan anak tuna rungu wicara dalam pembelajaran matematika dasar pada materi penjumlahan, pengurangan, perkalian dan pembagian, yang nantinya dapat memberikan solusi apabila terdapat permasalahan terkait pembelajaran matematika dasar pada empat materi tersebut. Metode dalam penelitian ini adalah penelitian kualitatif deskrtiptif. Subjek sebanyak 6 anak tuna rungu wicara, dipilih secara random sampling dari 29 anak tuna rungu wicara. Objek penelitian ini adalah kebutuhan dan perilaku anak tuna rungu dan wicara dalam pembelajaran matematika dasar di SKh Kabupaten Pandeglang. Teknik pengambilan data pada penelitian ini yaitu wawancara, observasi dan dokumentasi. Instrument penenlitian yang digunakan yaitu membuat pertanyaan untuk wawancara, observasi melihat langsung kegiatan pembelajaran matematika di kelas, dan dokumentasi melihat dokumen-dokumen pembelajaran matematika di SKh. Hasil penelitian menunjukkan bahwa kebutuhan anak tuna rungu dan wicara adalah media pembelajaran, alat peraga matematika, perbendaharaan kata, dan pemahaman materi yang baik. Perilaku anak tuna rungu dan wicara yaitu mereka menyukai pelajaran matematika dasar tergantung pada mudah atau tidak mudahnya materi. Apabila materi mudah, anak tuna rungu wicara sangat antusias dalam belajar dan sebaliknya. Anak tuna rungu wicara dapat berkonsetrasi dengan baik di kelas pada saat kegiatan pembelajaran matematika dasar. Anak tuna rungu wicara dapat memahami materi matematika dengan baik. Anak tuna rungu wicara memiliki harga diri yang tinggi, disiplin, jiwa kompetisi, dan dapat menerima kekalahan. Anak tuna rungu wicara senang dalam pembelajaran matematika dasar.
\end{abstract}

Kata Kunci: Tuna rungu-wicara; Perilaku; Kebutuhan; Matematika Dasar

\begin{abstract}
This study aims to determine the needs and behavior of Deaf and Speech children in learning basic mathematics at the Special School of Pandeglang Regency. This research is important to do to find out how the behavior and needs of deaf children in learning basic mathematics in the material of addition, subtraction, multiplication and division, which later can provide solutions if there are problems related to basic mathematics learning in these four materials. The method in this research is descriptive qualitative research. The subjects were 6 deaf children, selected by random sampling from 29 deaf children. The object of this research is the needs and behavior of deaf and speech children in learning basic mathematics at SKh Pandeglang Regency. The data collection techniques in this study were interviews, observation and documentation. The research instruments used were making questions for interviews, observing first-hand observation of mathematics learning activities in class, and
\end{abstract}


documentation of viewing mathematics learning documents at SKh. The results showed that the needs of children with hearing and speech are learning media, mathematics teaching aids, vocabulary, and good understanding of the material. The behavior of children who are deaf and speech is that they like basic math lessons depending on the ease or difficulty of the material. If the material is easy, the speech hearing deaf child is very enthusiastic in learning and vice versa. Children with hearing hearing impairment can concentrate well in class during basic mathematics learning activities. Children with hearing hearing impairment can understand math material well. Children with hearing hearing impairment have high self-esteem, discipline, a competitive spirit, and can accept defeat. On average, children with hearing hearing impairment enjoy learning basic mathematics

Keywords: Deaf-speech; Behavior; Needs; Basic Mathematics

\section{PENDAHULUAN}

Dalam hal pendidikan, Anak Berkebutuhan Khusus (ABK) memiliki hak yang sama dengan anak normal, sesuai dengan UUD 1945 pasal 31 ayat 1 dan UU Nomor 20 tahun 2003 tentang Sistem Pendidikan Nasional bab IV pasal 5 ayat 1 menyatakan bahwa setiap warga negara mempunyai hak yang sama untuk memperoleh pendidikan yang bermutu. Warga negara yang memiliki kelainan fisik, emosional, mental, intelektual atau sosial berhak memperoleh pendidikan khusus. Hal ini menunjukkan bahwa anak yang memiliki hambatan, kelainan/memiliki kemampuan potensi kecerdasan dan bakat istimewa berhak pula memperoleh kesempatan yang sama dengan anak normal dalam layanan pendidikan.

Anak dikatakan berkebutuhan khusus jika ada sesuatu yang kurang atau bahkan lebih didalam dirinya. ABK membutuhkan pelayanan pendidikan khusus, agar potensinya dapat berkembang secara optimal. Konsep ABK memiliki makna dan lingkup yang lebih luas dibandingkan dengan konsep anak luar biasa (Dedy, 2012:23). ABK merupakan anak yang memerlukan penanganan khusus karena adanya gangguan perkembangan dan kelainan yang dialami anak (Desiningrum, 2016:1). Sedangkan menurut Alimin (2012:1) ABK merupakan anak-anak yang memiliki hambatan perkembangan dan hambatan belajar termasuk di dalamnya anak-anak penyandang cacat. Mereka membutuhkan pelayanan yang khusus dalam pendidikan, agar hambatan belajar dapat dihilangkan dan kebutuhannya dapat terpenuhi. ABK merupakan mereka yang memiliki kebutuhan khusus sementara maupun permanen sehingga membutuhkan pelayanan pendidikan yang lebih intens (Illahi, 2013:138). Berdasarkan beberapa pendapat ahli tersebut disimpulkan bahwa ABK adalah anak yang memiliki kelebihan dan kekurangan pada dirinya baik secara mental maupun fisik sehingga membutuhkan perlakuan yang khusus dalam pendidikan.

Berdasarkan Undang-Undang dalam hal pendidikan yang sudah dijelaskan sebelumnya, ABK membutuhkan perlakuan yang khusus dalam belajar. Termasuk belajar mata pelajaran matematika, keterbatasan ABK dalam modalitas mempelajari matematika diperlukan modifikasi kearah konkrit dan funsioanal (disesuaikan dengan indera yang masih berfungsi). Pembelajaran matematika bagi ABK agar mampu digunakan dalam kehidupan, pekerjaan, keluaraga dan masyarakat. Kemampuan matematika dasar bagi ABK penting untuk menunjang kehidupan sehari-hari. Oleh karena itu diperlukan penanganan dan kesempatan belajar matematika yang baik perlu disediakan oleh guru. Kemampuan matematika dasar untuk ABK tentu memerlukan perhatian khusus dan metode pembelajaran yang variatif (Mumpuniarti, 2011:20). Metode belajar yang variatif, inovatif, dan menarik dapat menjadikan proses belajar matematika di kelas menjadi menyenangkan, terhibur, dan memudahkan anak untuk paham (Maswar, 2019:29). Sudah semestinya guru sebagai pendidik harus memberikan pelayanan terbaik untuk anak didiknya sehingga dapat 
menghilangkan anggapan siswa yang kurang baik terhadap pembelajaran matematika, dengan demikian proses pembelajaran dapat berjalan dengan baik.

ABK memiliki ragam jenisnya, namun dalam penelitian ini hanya tuna rungu-wicara yang menjadi subjek penelitian. Menurut Desiningrum (2016:7-8) tuna rungu yaitu anak yang kehilangan seluruh/sebagian daya pendengarannya sehingga tidak/kurang mampu berkomunikasi secara verbal. Tunawicara yaitu anak yang mengalami kelainan suara, pengucapan/kelancaran bicara, yang mengakibatkan terjadi penyimpangan bentuk bahasa, isi bahasa/fungsi bahasa. Tuna rungu merupakan keadaan kehilangan pendengaran meliputi seluruh tingkatan baik ringan, sedang, berat, dan sangat berat yang akan mengakibatkan pada gangguan komunikasi dan bahasa (Fidiawati, 2012:9). Gangguan komunikasi disebut juga tunawicara yaitu seorang yang tidak dapat berkomunikasi dengan baik. Anak yang mengalami gangguan pendengaran total otomatis akan terganggu bicaranya sehingga tuna rungu wicara saling berkaitan. Menurut Purwanto (1998) Tuna rungu-wicara memiliki kecerdasan yang sama seperti anak normal hanya saja pada kecerdasan verbal lebih rendah dari kecerdasan performance-nya. Meskipun demikian, anak tuna rungu-wicara membutuhkan bantuan khusus dalam pembelajaran matematika dasar selain itu harus diketahui juga seperti apa perilaku mereka dalam pembelajaran matematika dasar.

Beberapa penelitian terkait tuna rungu-wicara: (1) Solikhatun (2013) meneliti tentang penyesuaian sosial pada penyandang tuna rungu di SLB Negeri Semarang. Hasil penelitian menunjukkan bahwa subjek pada penelitian ini cenderung memiliki rasa kurang percaya diri dan minder. (2) Suherman dan Hidayat (2016) meneliti tentang komunikasi matematis siswa tuna rungu pada pembelajaran matematika di SMPLB-B PKK Provinsi Lampung. Hasil penelitian ini yaitu siswa merasa lebih nyaman menerima pembelajaran dengan menggunakan metode ceramah berbasis bahasa isyarat, metode oral, dan tulisan, tetapi pemahaman konsep dan kemampuan matematis siswa tuna rungu masih tergolong rendah. (3) Sediyono dan Malatista (2010) meneliti tentang model pembelajaran matematika untuk siswa kelas IV SDLB penyandang tuna rungu dan wicara dengan metode komtal berbantuan komputer. Hasil penelitian menunjukkan bahwa metode komtal melalui bantuan computer dapat digunakan untuk model pembelajaran, karena mampu meningkatkan prestasi siswa dalam belajar berdasarkan nilai yang diperoleh para siswa. (4) Vitovaa dan Balcarova (2012) hasil penelitian menunjukkan tingkat imajinasi pratematis anak tuna rungu pada anak prasekolah dipengaruhi oleh tingkat keterampilan bahasa mereka. (5) Kelly dan Gaustad (2007) hasil penelitian menyatakan nilai siswa tuna rungu yang mengikuti mata pelajaran matematika meningkat secara signifikan dan berhubungan positif dengan peningkatan nilai membaca dan pengetahuan morpologi mereka yaitu seluk beluk bentuk kata serta pengaruh perubahan bentuk kata terhadap golongan dan arti kata. (6) Adin, J., et, al (2014) hasil penelitian menunjukkan bahwa hasil tes tidak terdapat perbedaan antar kemampuan fonologi, pengurangan dan penalaran perkalian, tetapi daya tangkap yang tidak menggunakan isyarat lebih baik dibandingkan yang menggunakan isyarat dalam perkalian. (7) Ashori (2020) hasil penelitian menyatakan pendengaran pada anak-anak Cochlear Implant (CI) lebih baik dari pada anak-anak dengan Hearing Aid (HA). Penelitian ini menyoroti pentingnya Cochlear Implant (CI) pada anak kecil karena dampak signifikannya sangat terlihat pada pendengaran anak tuna rungu wicara. (8) Kritzer, L, Karen (2009) menunjukkan bahwa sebelum memasuki sekolah formal anak tuna rungu sudah menunjukkan bakat keterampilan akademiknya. Dilihat dari hasil tes anak tuna rungu usia 4-6 tahun kemampuan keterampilan akademik di atas rata-rata. Berdasarkan beberapa penelitian yang sudah dilakukan, perbedaan penelitian ini dengan penelitian lain adalah tempat penelitian dilakukan di Kabupaten Pandeglang, menganalisis kebutuhan, dan perilaku anak tuna rungu-wicara dalam pembelajaran matematika. Penelitian ini penting 
dilakukan karena untuk mengetahui bagaimana perilaku dan kebutuhan anak tuna rungu dalam pembelajaran matematika dasar yaitu materi penjumlahan, pengurangan, perkalian dan pembagian yang kemudian nantinya dapat diberikan solusi apabila terdapat permasalahan terkait pembelajaran matematika dasar pada empat materi tersebut.

Kabupaten Pandeglang merupakan salah satu kabupaten di Provinsi Banten. Jumlah Sekolah Berkebutuhan Khusus di Kabupaten Pandeglang yaitu 19 sekolah. Penelitian berkaitan dengan tuna rungu-wicara di Kabupaten Pandeglang belum begitu banyak. Khususnya pembelajaran matematika, belum ada yang meneliti kebutuhan dan perilaku anak tuna rungu-wicara di Kabupaten Pandeglang. Hasil wawancara prapenelitian peneliti dengan kepala SKh Pembina Pandeglang 1 dan SKh Korpri menyatakan bahwa belum ada penelitian terkait tuna rungu wicara dalam pembelajaran matematika dasar. Selain itu, pencarian hasil penelitian terkait tuna rungu wicara dalam pembelajaran matematika dasar di Kabupaten Pandeglang belum peneliti temukan, hanya ada satu penelitian yang membahas anak berkebutuhan khusus yaitu penelitian yang dilakukan oleh Rizky dan Hakim (2019) menyatakan bahwa metode forward chaining adalah metode yang berbasis aturan pas jika untuk menentukan karakter siswa dengan kebutuhan khusus, penelitian ini memberikan kontribusi di dalam ilmu keguruan bagian bimbingan konseling dan ilmu komputer khususnya di bidang sistem pakar. Berdasarkan latar belakang tersebut, perlu dilaksanakan penelitian "Analisis Kebutuhan dan Perilaku Anak Berkebutuhan Khusus (Tuna Rungu dan Wicara) dalam Pembelajaran Matematika Dasar di- Sekolah Khusus (SKh) se- Kabupaten Pandeglang". Tujuan dalam penelitian ini adalah (1) untuk mengetahui apa saja kebutuhan pembelajaran matematika dasar bagi anak tuna rungu-wicara, faktor-faktor pendukung pembelajaran, metode tepat guna apa saja yang bisa guru terapkan, (2) untuk mengetahui perilaku siswa ABK tuna rungu-wicara terhadap pelajaran matematika dasar, (3) mengetahui bagaimana anak tuna rungu wicara memecahkan permasalahan matematika dasar dan membantu memberikan solusi agar lebih baik hasil belajar matematika dasar.

\section{METODE PENELITIAN}

Penelitian ini merupakan penelitan kualitatif deskriptif. Subjek dalam penelitian ini adalah siswa ABK (Tuna rungu-wicara) se-Kabupaten Pandeglang. Sekolah Kebutuhan Khusus (SKh) di Kabupaten Pandeglang berjumlah 19 sekolah, namun untuk penelitian ini sampel yang diambil adalah 2 Sekolah Kebutuhan Khusus (SKh) yaitu SKh Korpri Pandeglang dan SKh 01 Pembina Pandeglang. Dari total keseluruhan anak tuna rungu wicara dari kedua sekolah tersebut adalah 29 siswa dengan rincian SKh Korpri Pandeglang berjumlah 14 anak tuna rungu wicara dan SKh 01 Pembina Pandeglang berjumlah 15 anak tuna rungu wicara, namun hanya 6 anak dan 6 guru tuna rungu wicara yang menjadi subjek dari penelitian ini dikarenakan waktu dan kondisi yang tidak memungkinkan untuk mengabil semua data anak maupun guru tuna rungu wicara. Pengambilan subjek ini dilakukan secara random sampling masing-masing sekolah dipilih 3 siswa dan 3 guru tuna rungu wicara. Waktu pelaksanaan kegiatan penelitian dilakukan pada bulan April sampai dengan September tahun 2020.

Teknik pengumpulan data dengan cara observasi, wawancara, dan dokumen. Instrument penelitian yang digunakan yaitu membuat pertanyaan untuk wawancara terkait kebutuhan dan perilaku anak tuna rungu wicara, observasi menggunakan lembar observasi untuk melihat perilaku anak tuna rungu wicara secara langsung kegiatan pembelajaran matematika di kelas, dan dokumentasi melihat dokumen-dokumen seperti RPP, silabus dan buku paket terkait pembelajaran matematika di SKh. Pada teknik pengumpulan data 
melalui wawancara peneliti membuat pertanyaan terkait kebutuhan dan perilaku anak tuna rungu wicara dalam pembelajaran matematika dasar yang ditujukan untuk guru dan siswa. Pada instrument observasi, peneliti menggunakan lembar observasi untuk melihat perilaku anak tuna rungu wicara dalam pembelajaran matematika dasar (materi penjumlahan, pengurangan, perkalian, dan pembagian).

Dalam penelitian kualitatif instrument utamanya adalah penelitian itu sendiri. Data utama penelitian ini berupa informasi tentang proses pembelajaran matematika dasar dan analisis perilaku serta kebutuhan siswa $\mathrm{ABK}$ tuna rungu wicara selama proses pembelajaran matematika, yang meliputi kesiapan guru sebelum pembelajaran, pelaksanaan pembelajaran, evaluasi dan tindak lanjut serta faktor pendukung pembelajaran, metode tepat guna dalam pembelajaran, pemecahan masalah dalam matematika dasar, kendala yang dialami ABK tuna rungu dan wicara selama proses pembelajaran. Data utama tersebut didapat dari hasil wawancara, lembar observasi, dan dokumen dari guru. Data tersebut diperoleh dari hasil wawancara, observasi, dan dokumen. Wawancara dilakukan sebanyak tiga kali. Observasi dilakukan sebanya ktiga kali, metode observasi yang digunakan dalam penelitian ini adalah metode observasi pasif yaitu peneliti hanya mengamati proses pembelajaran yang dilakukan guru serta anak tuna rungu wicara dengan menggunakan lembar observasi. Serta ditambah dengan informasi dari dokumen sekolah ABK seKabupaten Pandeglang.

Teknik analisis data yang digunakan adalah reduksi data, penyajian data, dan penarikan kesimpulan.Validasi data menggunakan triangulasi sumber, yaitu dengan menyocokkan hasil observasi, hasil wawancara, hasil dokumen pertama, kedua dan ketiga. Sehingga dari hasil pengambilan data sebanyak tiga kali tersebut diperoleh data kegiatan pembelajaran matematika berdasarkan hasil rekaman wawancara, melihat langsung (divideokan dan foto) pada saat guru mengajarkan matematika dasar, dan melihat dokumen RPP, silabus, serta buku paket yang digunakan guru. Khususnya dalam kebutuhan dan perilaku ABK (Tuna rungu-wicara) di Kabupaten Pandeglang. Setelah data didapat kemudian dianalisis, selanjutnya dideskripsikan dengan jelas pada hasil penelitian.

\section{HASIL DAN PEMBAHASAN}

Penelitian ini dilaksanakan di dua sekolah berkebutuhan khusus Kabupaten Pandeglang, yaitu SKh Pembina Pandeglang 1 dan SKh Korpri Pandeglang. Total subjek pada penelitian ini berjumlah 6 anak tuna rungu wicara dan 6 guru SKh tuna rungu wicara. SKh Pembina Pandeglang 1 adalah SKh Negeri di Kabupaten Pandeglang sedangan SKh Korpri adalah SKh Swasta di Kabupaten Pandenglang. Jenjang pada SKh Korpri mulai dari tingkat TK, SD, SMP, dan SMA. Jenjang pada SKh Pembina Pandeglang 1 mulai dari SD, SMP, dan SMA. Pada kedua sekolah tersebut tidak hanya anak tuna rungu wicara saja, anak berkebutuahan khusus lainnya pun ada yaitu tunagrahita, tunanetra, autis, down syndrome dan sebagainya.

Hasil penelitian menunjukkan bahwa anak tuna rungu wicara adalah anak yang tidak bisa mendengar dan berbicara artinya dalam kemampuan bahasa mereka sangat miskin sekali. Sehingga, anak tuna rungu wicara harus menggunakan bahasa isyarat untuk berkomunikasi. Oleh karena itu, sangat setuju sekali bahwa seseorang dikatakan tuna rungu-wicara apabila mereka kehilangan daya dengarnya sedemikian rupa sehingga untuk pengembangan potensinya diperlukan pendidikan khusus. Menurut David (2009:274) klasifikasi berkurangnya pendengaran menurut lokasi anatomis meliputi: (a) Conductive Hearing Loss, adalah kondisi berkurangnya kemampuan mendengar dikarenakan rusaknya organ fisik dari telinga; (b) Sensorineural Hearing Loss, adalah kondisi berkurangnya 
kemampuan mendengar dikarenakan rusaknya syaraf organ telinga; (c) Mixed Hearing Loss, adalah kondisi berkurangnya kemampuan mendengar dikarenakan rusaknya organ fisik dari telinga dan rusaknya syaraf organ telinga. Tuna rungu-wicara adalah individu yang memiliki hambatan dalam pendengaran baik permanen maupun tidak permanen. Klasifikasi tuna rungu-wicara berdasarkan tingkat gangguan pendengaran adalah: (1) Gangguan pendengaran sangat ringan (27-40dB); (2) Gangguan pendengaran ringan (4155dB); (3) Gangguan pendengaran sedang (56-70dB); (4) Gangguan pendengaran berat (71-90dB); (5) Gangguan pendengaran ekstrem/tuli (di atas 91dB). Pada penelitian ini, subjek yang banyak diambil adalah dari 6 anak tuna rungu wicara, 5 anak tuna rungu wicara murni dan 1 anak tuna rungu wicara plus c (terdapat tunagrahita sedang).

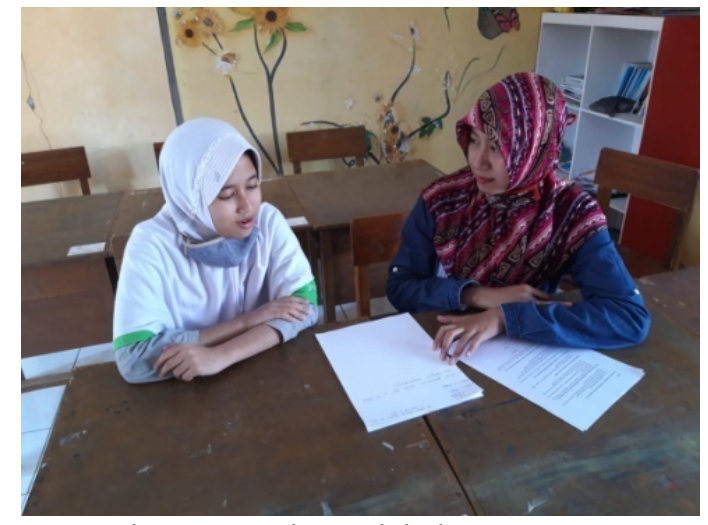

Gambar 1. Peneliti melakukan wawancara melalui tulisan dengan pertanyaan yang sederhana kepada anak tuna rungu wicara murni di SKh Korpri Pandeglang.

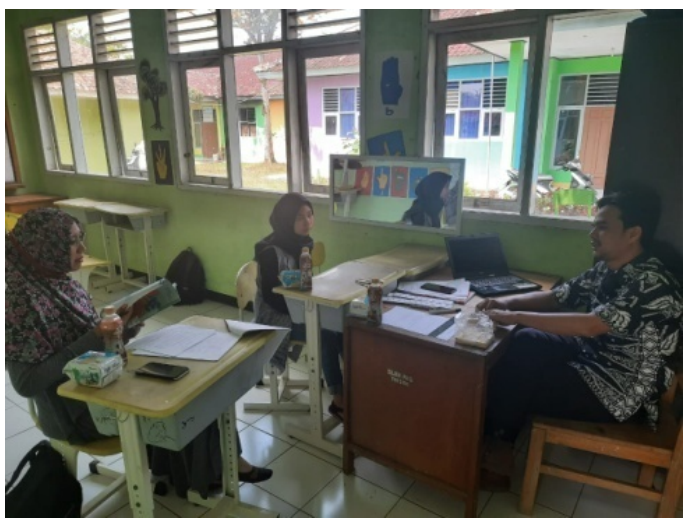

Gambar 2. Peneliti mengikuti proses pembelajaran matematika dasar dan wawancara anak tuna rungu murni serta guru pendamping di SKh Pembina Pandeglang 1

Anak tuna rungu wicara murni sama saja dengan anak normal lainnya mereka ada yang ceria, introvert, tidak mau diam, ada yang malas, rajin, disiplin, mudah menyerah, gigih, pintar, ada yang biasa saja kemampuan intelegensinya, ada juga kemampuan intelegensinya di atas, ketika diberikan media contoh uang dalam pengoperasian matematika dasar mereka sangat cepat menjawab dengan benar, dan lain sebagainya. Pernyataan tersebut berasal dari hasil wawancara peneliti dengan anak tuna rungu murni dibantu oleh guru untuk menerjemahkan melalui bahasa isyarat dan hasil wawancara dengan guru tuna rungu wicara terkait siswa terseut. Berikut di bawah ini hasil wawancara dengan salah satu siswa tuna rungu wicara, peneliti menyebut siswa dengan panggilan Ade:

Peneliti : Ade suka pelajaran matematika? Kenapa?

Siswa 1 : Suka tapi tidak terlalu, karena saya suka pelajaran bahasa inggris, IPA, dan seni lukis/gambar

Peneliti : Menurut Ade belajar matematika susah tidak? Susahnya dimana?

Siswa 1 : Tidak susah, saya belajar. Kalau tidak bisa saya belajar lagi nanti juga bisa.

Peneliti : Apa yang ade butuhkan/harapkan dalam pembelajaran matematika, inginnya seperti apa pembelajaran matematika di kelas?

Siswa 1 : Harus lebih menyenangkan lagi

Peneliti : Ade suka mengerjakan tugas matematika? dibantu orangtua atau mengerjakan sendiri?

Siswa1 : Suka mengerjakan tugas, kalau materi baru belum paham pasti saya minta dibimbing oleh ibu di rumah atau bapak ibu guru kalau di sekolah. Kalau materi yang sudah diajarkan dan saya paham, saya akan mengerjakan tugas sendiri.

Peneliti : Ade bisa menghitung sendiri? Tanpa harus didampingi oleh guru?

Siswa 1 : Bisa

Peneliti : Kalau diajarkan oleh ibu guru pelajaran matematika cepat memahami tidak?

Siswa 1 : Bisa memahami, kalau tidak paham pelajari lagi 


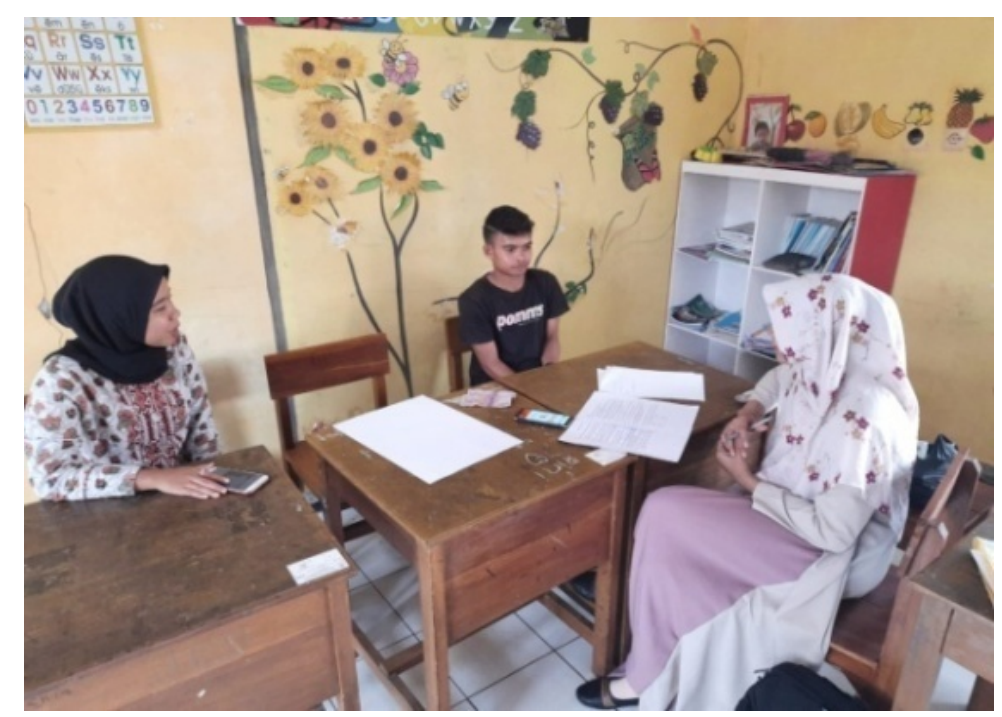

Gambar 3. Proses Wawancara denga Anak tuna rungu wicara plus c (terdapat tunagrahita sedang) dan guru pendamping

Anak tuna rungu wicara plus c (terdapat tunagrahita sedang), pada penelitian ini peneliti mendapatkan satu subjek anak tuna rungu wicara plus c (terdapat tunagrahita sedang) yaitu anak tidak bisa mendengar, berbicara dan kemampuan kognitifnya di bawah anak normal. Pada anak tipe ini, untuk perilaku/sikap sama seperti anak normal lainnya. Hanya saja dalam belajar menerima materi matematika dasar anak tipe ini sangat sulit, contoh mereka lebih cepat bosan dalam belajar matematika di kelas, gampang menyerah, lebih senang kegiatan yang melibatkan fisik, jarang mengerjakan tugas, ketika berhitung angka anak tipe ini tidak bisa mengerjakan sendiri (harus benar-benar dibimbing oleh bapak/ibu guru SKh), tetapi ketika diberikan pertanyaan soal penjumlahan dan pengurangan dengan media uang nyata anak tipe ini bisa menjawab tanpa waktu lama. Pada materi perkalian dan pembagian, anak tipe ini sangat sulit untuk menjawabnya dan diakhiri dengan bahasa isyarat tidak tahu. Berikut di bawah ini percakapan peneliti dengan siswa tuna rungu wicara plus c dibantu guru pendamping untuk menerjemahkan ke dalam bahasa isyarat.

Peneliti : Ade suka pelajaran matematika? Kenapa?

Siswa 2 : Tidak suka, alasannya tidak tahu. Kalau menghitung uang saya suka.

Peneliti : Menurut Ade belajar matematika susah tidak? Susahnya dimana?

Siswa 2 : Tidak tahu

Peneliti : Apa yang ade butuhkan dalam pembelajaran matematika, inginnya seperti apa pembelajaran matematika di kelas itu?

Siswa 2 : Tidak tahu

Peneliti : Ade suka mengerjakan tugas matematika? dibantu orang tua atau mengerjakan sendiri?

Siswa 2 : Suka mengerjakan tugas, dikerjakan sendiri tetapi tidak tahu

Peneliti : Ade bisa menghitung sendiri? Tanpa harus dibantu oleh guru?

Siswa 2 : Bisa menghitung kalau menggunakan benda nyata contoh uang

Peneliti : Kalau diajarkan oleh ibu guru pelajaran matematika cepat memahami tidak?

Siswa 2 : Bisa tapi butuh waktu yang lama

Anak tuna rungu wicara belajar di sekolah, lebih banyak ditekankan kedalam keterampilan, jadi $70 \%$ pembelajaran keterampilan dan 30\% pembelajaran umum, tujuannya agar mereka bisa mandiri dimasyarakat. Selain itu, terdapat anak tuna rungu wicara yang melanjutkan pendidikan kejenjang perguruan tinggi, bekerja di kantor, dan bekerja di sekolah. Rata-rata anak tuna rungu wicara memiliki kelebihan dibidang keterampilan 
contoh melukis, menjahit, membuat komik, pantomim, menguasai komputer (desain grafis), merajut, dan lain sebagainya.

Kebutuhan pembelajaran matematika bagi anak tuna rungu wicara. Anak tuna rungu wicara dalam pembelajaran matematika di kelas dapat mengikuti dengan baik. Anak tuna rungu wicara dalam belajar matematika harus menggunakan media atau alat peraga matematika agar bisa memahami konsep matematika dengan baik. Pada penelitian ini berkaitan dengan matematika dasar yaitu empat operasi dasar matematika (penjumlahan, pengurangan, perkalian, dan pembagian). Untuk menjelaskan penjumlahan, guru harus mengenalkan simbol matematika penjumlahan, kemudian diartikan ke dalam bahasa Indonesia, kemudian diartikan ke dalam bahas isyarat dan harus diucapakan dengan gerak bibir yang jelas. Mengajar tuna rungu wicara guru wajib menggunakan tiga cara menyampaikan materi yaitu menggunakan gambar/symbol/lambang, bahasa isyarat, dan bahasa oral. Sama halnya dengan pengurangan, perkalian dan pembagian. Hal tersebut berdasarkan dari 6 sumber guru tuna rungu wicara melalui hasil wawancara. Salah satu petikan wawancara dengan guru tuna rungu wicara:

Peneliti : Bagaimana cara menyampaikan materi matematika dasar pada anak tuna rungu wicara? Guru 6 : Caranya harus dengan benda, dan harus menggunakan bahasa total yaitu bahasa isyarat, oral dan visual, konsep-konsep dasarnya dulu disampaikan, sampaikan dulu perkata-perkata operasi penjumlahan pengurangn, perkalian, dan pembagian, kalau menggunakan teori mereka sangat susah untuk memahami. Point dari bidang matematika penyelesaian matematika lebih efektif dengan metode secara real dengan ada benda nyata karena lebih paham anak-anaknya, oleh karena itu guru harus paham dan mampu membuat media atau alat peraga (kreatif). Tiga konsep dalam belajar anak tuna rungu wicara yaitu belajar bahasa, belajar oral mempelajari anakmengucapkan bahasa bibir, dan bahasa oral (mengenal bentuk, mengenal tulisan, dan mengenal bahasa bibirnya).

Kebutuhan anak tuna rungu wicara dalam belajar matematika dasar adalah media/alat peraga/benda yang nyata untuk dijadikan bahan representasi dari soal, buku materi matematika dasar, suasana kelas yang menyenangkan, pembelajaran harus konkrit, dan pemahaman yang baik. Anak tuna rungu wicara lebih cenderung praktik dibandingkan dengan teori-teori, karena dengan praktik mereka cepat memahami. Materi matematika sesuai dengan kurikulum dari pemerintah namun, untuk anak tuna rungu selalu dimodifikasi menjadi lebih sederhana sesuai dengan kemampuan anak. Suasana hati anak tuna rungu wicara sama saja dengan anak normal jadi guru harus sekreatif mungkin untuk menghidupkan suasana belajar menyenangkan di kelas. Pembelajaran matematika dasar pada anak tuna rungu wicara harus dikaitkan dengan kondisi nyata (dalam kehidupan sehari-hari) dengan cara ini mereka akan cepat paham. Untuk itu pemahaman konsep dasar pada matematika dasar harus wajib dimiliki oleh anak tuna rungu wicara. Apabila mereka belum paham, guru akan terus mengulang pelajaran sampai paham.

Kesulitan pada anak tuna rungu wicara dalam pembelajaran matematika dasar adalah mereka sulit untuk mengerjakan soal perkalian dan pembagian dengan angka ratuasan dengan puluhan, ribuan dengan puluhan, angka-angka di atas dua digit mereka sudah pusing. Hanya beberapa anak yang dapat menyelesaikan perkalian dan pembagian di atas dua angka. Selain itu, anak tuna rungu wicara kesulitannya ada pada memahami kalimat atau bacaan. Hal ini dikarenakan anak tuna rungu wicara miskin bahasa sehingga kosa kata pada mereka pun hanya beberapa bisa dipahami. Guru biasanya selalu memberikan katakata yang harus anak ingat dan pahami, untuk memahami kata pun anak tuna rungu wicara membutuhkan waktu yang lama harus terus diulang-ulang agar ingat. Kesulitan lainnya, pada materi bilangan bulat negatif, mereka tidak mengerti simbol negatif pada bilangan, 
ketika diberikan soal $-5+3=-2$ banyak sekali siswa yang tidak menjawab -2 . Materi pecahan sederhana, mereka bisa mengerjakan tetapi materi pecahan yang tidak sederhana mereka banyak mengalami kesulitan dalam memahami maupun mengerjakan soal-soalnya. Berdasarkan kesulitan tersebut dapat disimpulkan bahwa anak tuna rungu wicara sangat sulit memahami soal-soal matematika bentuk cerita, bilangan bulat negatif, dan pecahan tidak sederhana dan lain sebagainya. Hal tersebut, berdasarkan hasil wawancara dengan 6 siswa dan guru tuna rungu wicara, serta observasi di lapangan melihat proses pembelajaran matematika. Berikut di bawah ini beberapa hasil wawancara dengan guru tuna rungu wicara:

Peneliti : Apa sajakah kesulitan siswa tuna rungu wicara dalam belajar matematika dasar?

Guru 1 : Bagian pertanyaan cerita agak susah, kalau ujian nasional mereka agak susah menagkap soal-soal cerita makanya soal-soalnya disederhanakan ceritanya (kalimatnya disederhanakan).

Guru 2 : Komunikasi, apabila anak komunikasinya kurang maka kami kesulitan untuk mengarahkannya. Kesulitannya apabila tidak ada alat peraga atau media susah untuk menjelaskan karena anak tuna rungu wicara harus melihat

Guru 3 : Penjumlahan pengurangan dan perkalian tidak ada kesulitan, yang sulit itu pembagian apalagi bagi kurung. Kesulitannya adalah cara penyampaian, kalau ada cara penyampaian yang pas pasti cepet bisa. Cukup lama untuk menghitung kadang mereka akan ngitungngitung pakai tangan.

Guru 4 : Kesulitannya di bahasa dan memahami bacaan karena mereka tidak bisa mengartikan dan menuliskan apa yang mereka lihat hanya beberapa kata. Perbendaharaan kata yang kurang.

Faktor-faktor pendukung pembelajaran matematika tuna rungu wicara. Belejar matematika untuk anak tuna rungu wicara harus didukung oleh media pembelajaran. Peneliti melihat dari hasil pengambilan data, bahwa untuk media pembelajaran matematika dari pemerintah sudah disediakan dengan baik namun tidak dijaga dengan baik, akibatnya banyak alat peraga atau media pembelajaran matematika hilang atau rusak. Dengan demikian, ketika peneliti bertanya kepada bapak/ibu guru SKh rata-rata mereka membuat media pembelajaran matematika sendiri sesuai dengan materi yang akan diajarkan. Tidak adanya infokus di ruang kelas anak tuna rungu wicara, infokus merupakan media pembelajaran efektif untuk anak tuna rungu wicara, karena anak tuna rungu wicara belajar dengan cara visual maka dengan infokus mereka jadi sangat mudah untuk belajar dan membantu guru dalam mengajar. Hal ini sudah diminta oleh para guru agar sekolah menyediakan infokus dan sedang diusahakan oleh pihak sekolah untuk menyediakan infokus disetiap kelas. Faktor pendukung lainnya adalah guru harus mengajarkan dengan metode pembelajaran total yaitu tulisan, bahasa isyarat, dan oral (pengucapan). Dukungan dari orang tua murid sangat mempengaruhi anak tuna rungu wicara dalam pembelajaran matematika dasar. Orang tua yang mengikuti perkembangan anaknya dengan baik, mau belajar bahasa isyarat dari sekolah, di rumah orang tua menyediakan/memfasilitasi kebutuhan anak dengan baik, mau memberikan waktunya untuk mengajarkan matematika di rumah, dan lain sebagianya. Anak tuna rungu wicara dengan dukungan penuh dari orang tuanya mereka sangat cepat memahami materi-materi matematika yang diajarkan oleh guru di sekolah. Rata-rata anak tuna rungu wicara yang seperti itu mereka dapat hidup mandiri dimasyarkat bahkan sampai melanjutkan pendidikan kejenjang lebih tinggi (bangku kuliah). Dukungan orang tua dengan mereka mau belajar bahasa isyarat dapat menjadi pengalaman sangat berharga dan ikatan batin yang sangat kuat untuk anak tuna rungu wicara. Hal ini diperkuat sesuai dengan pendapat Humpries, T., et al. (2019:136) "When parents, especially mothers, feel empowered and confident about the choices they make, this influences deaf children positively: they have better language development, emotional sensitivity, reading competence, and problem solving; and they display higher cognitive flexibility, better social competence, and less impulsive behavior". Ketika orang 
tua, terutama para ibu, merasa berdaya dan percaya diri tentang pilihan yang mereka buat (mendukung anaknya dengan baik), ini mempengaruhi anak-anak tuna rungu secara positif: mereka memiliki perkembangan bahasa yang lebih baik, kepekaan emosional, membaca kompetensi, dan pemecahan masalah; dan mereka menampilkan kognitif yang lebih tinggi fleksibilitas, kompetensi sosial yang lebih baik, dan perilaku yang tidak terlalu impulsive.

Metode tepat guna apa saja yang bisa guru terapkan. Metode pembelajaran matematika dasar pada anak tuna rungu wicara sama saja dengan metode pembelajaran pada umumnya, namun pada anak tuna rungu wicara metode pembelajarannya disederhanakan sesuai dengan kemampuan anak. Selama peneliti amati, metode pembelajaran pada anak tuna rungu wicara yaitu metode pembelajaran secara langsung keindividu, metode pembelajaran kontekstual, metode pembelajaran dengan cara bermain dan menyenangkan, metode role playing, metode pembelajaran ekspositori, metode pembelajaran latihan soal (drill), dan metode pembelajaran tutor sebaya. Metode pembelajaran secara langsung keindividu, karena dalam satu kelas anak tuna rungu wicara paling sedikit berjumlah satu dan paling banyak ada empat anak, pembelajarannya pun yaitu guru memberikan pembelajaran kesatu anak satu anak karena misalkan dari empat anak tersebut belum tentu mereka memiliki kemampuan yang sama. Metode pembelajaran kontekstual, guru selalu membawa benda untuk dijadikan media pembelajaran, contoh materi pengurangan $4-2=$ 2 , guru memberikan contoh dengan media kelereng menyediakan empat kelereng kemudian diambil dua kelerengnya dan sisanya adalah hasil dari pengurangan $4-2=2$. Berdasarkan media tersebut guru juga menjelaskan konsep penjumlahan, pengurangan, perkalian, dan pembagian. Metode pembelajaran menyenangkan, guru tuna rungu wicara biasanya akan mengikuti apa yang sedang anak-anak suka dan bicarakan sebelum masuk kelas, agar suasana kelas menyenangkan. Suka bermain dengan cara mengadakan kompetisi dengan teman kelasnya (apabila anak tuna rungu wicara lebih dari satu). Mengajak siswa keluar untuk belajar sambil bermain tradisional (engkle, kelereng, mengumpulkan krikil dll) yang kemudian dikaitkan dengan materi matematika dasar.

Metode role playing, guru meminta anak tuna rungu wicara untuk berperan sebagai penjual atau pembeli, dengan metode ini anak tuna rungu wicara sangat cepat paham apalagi berkaitan dengan uang. Guru memberikan kesempatan untuk anak tuna rungu wicara untuk melatih matematika dasar dengan cara langsung praktik kelapangan yaitu membawa mereka pergi ke pasar atau warung untuk belanja. Metode pembelajaran ekspositori, guru memberikan penjelasan konsep matematika dasar (penjumlahan, pengurangan, perkalian, dan pembagian) ke anak tuna rungu wicara, setelah diberikan penjelasan konsep matematika dasar dan mereka paham selanjutnya guru memberikan latihan soal. Metode pembelajaran latihan (drill), guru memberikan tugas soal-soal matematika untuk dikerjakan baik di sekolah maupun di rumah mulai dari tingkatan mudah sampai sulit. Metode pembelajaran tutor sebaya, metode ini sangat efektif sekali untuk anak tuna rungu wicara. Guru mengetahui kemampuan anak tuna rungu wicara yang baik dan tidak dalam memahami materi pelajaran. Anak tuna rungu wicara yang sudah paham, oleh guru diberikan tugas untuk mengajarkan kepada temannya yang belum paham, dan hasilnya anak tuna rungu wicara yang belum paham tersebut menjadi paham setelah dijelaskan oleh temannya. Menurut bapak/ibu guru metode pembelajaran tutor sebaya, yang mana anak lebih mengetahui kelemahan dan kelebihan temannya dengan baik dibandingkan guru, dikarenakan mereka sering berkomunikasi bercengkraman, canda gurau, curhat dan lain sebagainya dan anak tuna rungu wicara tidak malu-malu belajar dengan temannya.

Perilaku anak tuna rungu-wicara terhadap pelajaran matematika dasar. Anak tuna rungu wicara dalam pembelajaran matematika dasar di kelas sama saja seperti anak normal. Ada 
yang menyukai matematika dan ada yang tidak. Hal ini tergantung dari materi pelajarannya, apabila materi mudah maka anak akan senang belajar matematika dasar dan sebaliknya. Anak tuna rungu wicara dapat fokus dalam pembelajaran matematika di kelas, kurang lebih anak tuna rungu wicara dapat konsentrasi selama satu jam. Anak tuna rungu wicara mau tidak mau pasti mereka akan memperhatikan guru menjelaskan karena mereka hanya bisa melihat, jadi harus melihat guru menggunakan bahasa isyarat. Alangkah baiknya jendela di dalam kelas harus ada tirai atau penutup jendela agar anak tuna rungu wicara tidak terganggu konsentrasinya. Mengapa demikian, ketika peneliti lihat di lapangan apabila jendela di dalam kelas tidak ditutup kemudian di luar ada orang lewat atau benda yang menjadi pusat perhatian maka anak tuna rungu wicara ketika belajar konsentrasinya menjadi terganggu mereka akan melihat kejendela sehingga guru harus menjelaskan kembali materi matematika dasar. Anak tuna rungu wicara dapat memahami materi dengan baik. Setelah paham, mereka dapat menyelesaikan secara mandiri soal-soal matematika dasar bentuk sederhana. Untuk tingkatan soal sulit, mereka meminta bantuan kepada guru untuk membimbing ataupun kepada temannya untuk minta diajarkan. Anak tuna rungu wicara selalu mengerjakan tugas dengan baik untuk di sekolah ataupun di rumah. Mereka mengerjakan sendiri tugasnya, apabila menemukan kesulitan meminta tolong kepada orangtuanya untuk membimbing. Apabila mendapatkan nilai kecil anak tuna rungu wicara mau berusaha kembali dengan cara mengulang kembali materi sampai mereka bisa.

Anak tuna rungu wicara tidak memiliki rasa takut dalam pembelajaran matematika dasar, justru dipelajaran matematika ini yang pasti dan tidak terlalu banyak kalimat mereka suka. Anak tuna rungu wicara memiliki harga diri yang tinggi, disiplin, jiwa kompetisi, dan dapat menerima kekalahan. Harga diri yang tinggi, anak tuna rungu wicara memiliki rasa menyukai diri sendiri yang baik, mengapresiasi diri dengan baik, sehingga dapat menghargai diri dengan baik. Hal tersebut terbentuk karena lingkungan pada anak tuna rungu wicara yang peneliti lihat baik dari sekolah maupun keluarga adalah lingkungan yang positif sehingga mereka memiliki harga diri yang tinggi (sehat). Disiplin, anak tuna rungu wicara akan mengikuti apa yang sudah dijadwalkan dengan baik, bahkan ketika jam istirahat pun mereka tepat waktu, belum waktunya istirahat mereka tidak akan keluar kelas. Memiliki jiwa kompetisi, anak tuna rungu wicara memiliki rasa malu apabila mereka tidak bisa mengerjakan dengan baik, jadi mereka akan berusaha semaksimal mungkin agar tidak kalah dengan temannya. Menerima kekalahan, anak tuna rungu wicara ada yang dapat menerima kekalahan ada juga yang tidak. Dari hasil observasi, wawancara, dan dokumen peneliti dapat menyimpulkan rata-rata anak tuna rungu wicara senang dalam pembelajaran matematika dasar. Berikut di bawah ini tabel persentase hasil observasi untuk melihat perilaku anak tuna rungu wicara:

Tabel 1. Persentase Hasil Observasi

\begin{tabular}{lll}
\hline \multirow{2}{*}{ Perilaku } & \multicolumn{2}{c}{ Keterlaksanaan } \\
\cline { 2 - 3 } & Ya & Tidak \\
\hline BerdoaSebelumBelajar agar tenangdalam Belajar & $100 \%$ \\
Memperhatikan guru ketikamenjelaskanselam jam pelajaranberlangsung & $83 \%$ & $17 \%$ \\
Membuatcatatanrumus-rumus yang pentingsetelahbelajarmatematika & & $100 \%$ \\
Mengerjakansoalmatematikauntukmengasahkemampuan & $83 \%$ & $17 \%$ \\
Memintabantuantemanatau guru jikamengalamikesulitan & $83 \%$ & $17 \%$ \\
Seringberdiskusiuntukmemecahkanmasalahdalamsoalmatematika & $67 \%$ & $33 \%$ \\
Mengerjakansoal/tugas yang diberikan guru & $100 \%$ & \\
Mudahbosandalambelajarmatematika & $67 \%$ & $33 \%$ \\
Belajarlebihgiatketikamendapatkannilaikecildalammengerjakansoalmatematika & $100 \%$ & \\
Takut/minder ketikabelajarmatematika & $17 \%$ & $83 \%$ \\
\hline
\end{tabular}


Pemecahan masalah anak tuna rungu wicara dalam kemampuan matematika dasar. Anak tuna rungu wicara dapat memecahkan masalah matematika bentuk sederhana, berkaitan langsung dengan angka-angka contoh: $6+6=\ldots, 8-2=\ldots, 10: 2=\ldots, 7 \times 5=\ldots$ angka satu, dua, tiga digit mereka dapat menyelesaikan dengan baik. Pengoperasian penjumlahan, pengurangan, dan perkalian secara bersusun mereka dapat mengerjakan dengan baik. Untuk soal cerita mereka membutuhkan bantuan guru untuk memahami apa maksud dari soal tersebut. Pembagian bentuk kurung mereka kesulitan karena kurang paham. Hal wajib dalam memecahkan masalah agar anak tuna rungu wicara dapat memahami maksud dari soal adalah harus menggunakan media atau alat peraga atau bendanya serta diartikan kedalam bahasa isyarat. Solusi untuk pemecahan masalah anak tuna rungu wicara dalam kemampuan matematika dasar khusunya soal bentuk cerita adalah harus dilatih setiap hari minimal satu soal cerita untuk satu hari, perbendaharaan kata harus terus dilatih setiap hari juga, apabila terus diulang-ulang yakin mereka akan paham dan dapat menyelesaikan persoalan matematika dengan baik. Kemampuan menyelesaikan soal matematika dapat diperoleh dari banyaknya latihan soal yang dilakukan oleh anak. Jika anak melakukan latihan soal secara bertahap dan terus menerus maka akan menambah referensi tentang rumus-rumus maupun tekhnik menyelesaikan soal. Agar kegiatan ini berhasil tentunya perlu waktu, perhatian, dan kemauan guru/orang tua untuk selalu siap menemani, membimbing anak tuna rungu wicara belajar matematika dasar.

\section{SIMPULAN}

Berdasarkan hasil penelitian dan pembahasan tersebut, kesimpulan dari penelitian ini adalah kebutuhan anak tuna rungu wicara dalam pembelajaran matematika dasar yaitu media pembelajaran matematika, alat peraga matematika, infokus, perbendaharaan kata (kosa kata), dan pemahaman materi yang baik. Perilaku anak tuna rungu wicara terhadap pelajaran matematika yaitu mereka menyukai pelajaran matematika dasar tergantung pada mudah atau tidak mudahnya materi. Apabila materi mudah anak tuna rungu wicara antusias dalam belajar dan sebaliknya. Anak tuna rungu wicara dapat berkonsetrasi dengan baik di kelas pada saat kegiatan pembelajaran matematika dasar. Anak tuna rungu dapat memahami materi matematika dengan baik. Anak tuna rungu wicara memiliki harga diri yang tinggi, disiplin, jiwa kompetisi, dan dapat menerima kekalahan. Rata-rata anak tuna rungu wicara senang dalam pembelajaran matematika dasar.

Sebagai tindak lanjut dari hasil penelitian ini dapat dikemukakan beberapa saran bagi peneliti lain yang ingin melakukan penelitian berkaitan dengan kebutuhan dan perilaku tuna rungu wicara diantaranya: (1) rencanakan waktu dengan baik, sehingga pelaksanaan dapat sesuai dengan rencana yang telah disusun. (2) Dapat dilakukan di daerah yang lain, karena setiap daerah pasti memiliki perbedaan kebutuhan dan perilakunya. (3) Setelah mengetahui kebutuhan dan perilaku anak tuna rungu wicara dalam pembelajaran matematika, dapat dilanjutkan pada penelitian berikutnya berkaitan dengan penelitian pengembangan atau kuasi eksperimen untuk memberikan solusi terbaru dalam pembelajaran matematika anak tuna rungu wicara.

\section{UCAPAN TERIMAKASIH}

Penelitian ini didanai sepenuhnya oleh Direktorat Riset dan Pengabdian Masyarakat Kementrian Riset dan teknologi/Badan Riset dan Inovasi Nasional pada skema Penelitian Dosen Pemula (PDP) tahun 2020. 


\section{DAFTAR RUJUKAN}

Alimin, Z. (2012). Anak Berkebutuhan Khusus, Modul pada Universitas Pendidikan Indonesia: tidak diterbitkan.

Ashori, M. (2020). Speech intelligibility and auditory perception of pre-school children with Hearing Aid, Cochlear Implant and Typical Hearing. Journal of Otology , 15 (2020), 62-66.

David, S. J. (2009). Inklusi (Sekolah Ramah Untuk Semua). Bandung, Indonesia: Nuansa.

Desiningrum, R. D. (2016). Psikologi Anak Berkebutuhan Khusus. Yogyakarta, Indonesia: Psikosain.

Fidiawati, R. (2012). Peningkatan Kemampuan Artikulasi Melalui Metode Drill Pada Anak Tuna Rungu Kelas Dasar II di SLB-B YPPALB Kota Magelang. Yogyakarta: Skripsi Pendidikan Luar Biasa FIP UNY.

Humphries, T., Kushalnagar, P., Mathur, G., Napoli, D. J., Rathmann, C., \& Smith, S. (2019). Support for parents of deaf children: Common questions and informed, evidencebased answers. International journal of pediatric otorhinolaryngology, 118, 134-142.

Ilahi, M. T., \& Rose, K. R. (2013). Pendidikan Inklusif: Konsep \& Aplikasi.

Kelly, R. R., \& Gaustad, M. G. (2007). Deaf college students' mathematical skills relative to morphological knowledge, reading level, and language proficiency. Journal of deaf studies and deaf education, 12(1), 25-37.

Kritzer, K. L. (2009). Barely started and already left behind: A descriptive analysis of the mathematics ability demonstrated by young deaf children. Journal of Deaf Studies and Deaf Education, 14(4), 409-421.

Dedy, K. (2012). Pendidikan Inklusif dan Upaya Implementasinya. PT Luxima Metro Media. Jakarta.

Maswar, M. (2019). Strategi Pembelajaran Matematika Menyenangkan Siswa (MMS) Berbasis Metode Permainan Mathemagic, Teka-teki Dan Cerita Matematis. Alifmatika: Jurnal Pendidikan Dan Pembelajaran Matematika, 1(1), 28-43.

Mumpuniarti. (2011). Modul Materi Matematika Bagi SDLB Program Pendidikan dan Latihan Profesi Guru (PLPG). Yogyakarta: Program Studi Pendidikan Luar Biasa Fakultas Ilmu Pendidikan UNY.

Purwanto, H. (1998). Ortopedagogik umum. Yogyakarta: IKIP Yogyakarta.

Hakim, Z., \& Rizky, R. (2020). Sistem Pakar Menentukan Karakteristik Anak Kebutuhan Khusus Siswa Di SLB Pandeglang Banten Dengan Metode Forward Chaining. Jutis (Jurnal Teknik Informatika), 7(1), 93-97.

Malatista, B. R., \& Sediyono, E. (2010). Model Pembelajaran Matematika untuk Siswa Kelas IV SDLB Penyandang Tunarungu dan Wicara dengan Metode Komtal Berbantuan Komputer. Jurnal Teknik Informatika dan Sistem Informasi, 7(1), 219382.

Solikhatun, Y. U. (2013). Penyesuaian sosial pada penyandang tunarungu di SLB Negeri Semarang. Educational Psychology Journal, 2(1).

Hidayat, R., \& Suherman, S. (2016). Kemampuan Komunikasi Matematis Siswa Tunarungu Pada Pembelajaran Matematika di SMPLB-B PKK Provinsi Lampung. Jurnal Pendidikan Progresif, 6(1), 73-84. 
Vitova, J., \& Balcarova, J. (2012). Language competence versus the mathematical concepts of pre-school children with hearing impairments. Procedia-Social and Behavioral Sciences, 69, 2076-2081. 